\title{
The Uptake, Metabolism and Phytotoxicity of MCPA in Plants*
}

\author{
Nagi R. Achhireddy,** Ralph C. Kirkwood and William W. Fletcher \\ Department of Biology, University of Strathclyde, Glasgow, Scotland
}

(Received January 24, 1984)

\begin{abstract}
The phytotoxicity of MCPA (2-methyl-4-chlorophenoxyacetic acid) as related to the translocation and metabolism in maize (tolerant), chickweed (moderately sensitive), and broad bean (sensitive) were examined under controlled environmental conditions. The amount of ${ }^{14} \mathrm{C}$-MCPA translocated in broad bean and chickweed was significantly greater than in maize. However, retained by the treated leaf was greater in maize than in the other two species. The ${ }^{14} \mathrm{C}-\mathrm{MCPA}$ retained by the cuticle wax was less than $1 \%$ (of the applied) and the test species did not differ significantly in this respect. The release of ${ }^{14} \mathrm{CO}_{2}$ from ${ }^{14} \mathrm{C}-\mathrm{MCPA}$ was significantly greater in broad bean than in maize and chickweed. The foliar application of MCPA resulted in greater inhibition of ${ }^{14} \mathrm{CO}_{2}$ fixation and ${ }^{14} \mathrm{C}$-assimilate translocation in broad bean and chickweed than in maize.
\end{abstract}

\section{INTRODUCTION}

The selective control of broad-leaf weeds in grass or cereal crops has been achieved through the foliar application of 2-methyl-4-chlorophenoxyacetic acid (MCPA). There are a few reports which suggest that differences in phytotoxicity of MCPA are due to differentials in absorption, translocation and metabolism of the herbicide. ${ }^{1-3)}$ Most of these studies were conducted on a single sensitive plant or plants selected from a single group (dicotyledons), which differed in sensitivity to MCPA. Very little attention was given to compare the performance and selectivity with regard to uptake, translocation and metabolism of MCPA in different plants. We report in this paper,

* The data presented in this paper from a part of the Ph.D. thesis (1980) of N. R. Achhireddy approved by the University of Strathclyde, Glasgow, Scotland.

** Present address: Agricultural Research and Education Center, University of Florida, Institute of Food and Agricultural Sciences, Lake Alfred, FL 33850, USA. the phytotoxicity of MCPA as related to translocation and metabolism in maize (tolerant), chickweed (moderately sensitive), and broad bean (sensitive) under controlled environmental conditions.

\section{MATERIALS AND METHODS}

Maize (Zea mays L.), chickweed [Stellaria media (L.) Vill.], broad bean (Vicia faba L.) were grown in John Innes No. 3 compost in 10 $\mathrm{cm}$ polystyrene pots in heated greenhouse $(22$ $\left.\pm 2^{\circ} \mathrm{C}\right)$ under white fluorescent lights $(14 \mathrm{hr}$ photoperiod in a $24 \mathrm{hr}$ cycle). After germination, four uniform plants were allowed to establish per pot. The plants were sprayed just to runoff at four-leaf stage with various concentrations of herbicide ( $\mathrm{Na}$ salt). Polyoxyethylene sorbitan monolaurate (Tween-20) at $0.1 \%(\mathrm{v} / \mathrm{v}$, final concentration) was added to the herbicide solution before spraying. The herbicide treated plants were then placed in a growth chamber which was maintained at $20 \pm 0.5^{\circ} \mathrm{C}$ (air temperature), $150 \mu \mathrm{E} \mathrm{cm}-2 \mathrm{hr}^{-1}$ for $14 \mathrm{hr}$ in a 24 hr cycle. The relative humidity was maintained at $70 \pm 5 \%$. Seven days after treatment, visual ratings at 0 to 5 (0: no effect; 5 : severe wilting 
and blackening of leaves) were made on the test species.

For experiments involving the uptake and metabolism of MCPA, the plants were raised in the greenhouse as described above. There were two plants per pot. The specific activity of MCPA [2-methyl-4-chlorophenoxy $\left({ }^{14} \mathrm{C}\right)$-acetic acid] was $6.0 \mathrm{mCi} / \mathrm{mmol} .{ }^{14} \mathrm{C}-\mathrm{MCPA}(2.4$ $\mu \mathrm{g}, 0.06 \mu \mathrm{Ci}$ ) was applied to the fully expanded second leaf at four-leaf stage as two $2 \mu \mathrm{l}$ droplets to the adaxial surface in the middle on either side of the midrib. The surfactant Tween-20 at $0.1 \%(\mathrm{v} / \mathrm{v})$ was added to the labelled herbicide. The ${ }^{14} \mathrm{C}$-herbicide treated plants were then transferred to a growth chamber. The growth chamber conditions were similar to the ones described previously. On the 7th day after treatment, the plants were harvested for ${ }^{14} \mathrm{C}$ analysis. The treated leaves were cut and washed by gentle shaking with $10 \mathrm{ml}$ distilled water held in $125 \mathrm{ml}$ flasks for $2 \mathrm{~min}$ to remove surface residues of the herbicide and then in $10 \mathrm{ml}$ chloroform held in liquid scintillation vials for $15 \mathrm{sec}$ to remove the cuticle wax fraction. A $1 \mathrm{ml}$ aliquot of water wash was transferred to $10 \mathrm{ml}$ dioxan-based scintillation liquid ${ }^{4)}$ and radioassayed using a Packard Tricarb model 3375 liquid scintillation spectrometer. The chloroform extracts were evaporated to dryness, $10 \mathrm{ml}$ scintillator added and the sample radioassayed as before. The treated leaves, shoots, and roots were then separately homogenized in $20 \mathrm{ml}$ of $40 \%$ acetone using an Ultra-turrox model TP-1810 homogenizer and $0.5 \mathrm{ml}$ aliquot of the homogenate radioassayed. The degree of quenching was determined by internal standardization and all the values were corrected for quenching and counting efficiency.

An investigation of the possible release of ${ }^{14} \mathrm{CO}_{2}$ from ${ }^{14} \mathrm{C}$-MCPA treated test plants was carried out by determining the release of ${ }^{14} \mathrm{CO}_{2}$ during a 7-day period. The ${ }^{14} \mathrm{CO}_{2}$ evolved from the test species was trapped in $14 \%(\mathrm{v} / \mathrm{v})$ ethanolamine in methoxyethanol. The treated plants were placed in airtight kilner jars, one jar per species. The absorption system set up was similar to that described by Veerasekaran. ${ }^{5}$ The outlet tube led to three glass washing bottles in series, each containing $100 \mathrm{ml}$ of ethanolamine solution. The amount of ${ }^{14} \mathrm{CO}_{2}$ absorbed in ethanolamine was determined at 2, 5, and 7 days after treatment by radioassay of $1 \mathrm{ml}$ aliquots from each trap. Extraction of ${ }^{14} \mathrm{C}$ MCPA and its metabolites from the treated plants was carried out according to the methods described by Fawcett et al. ${ }^{6)}$ Briefly, the plants were homogenized, acidified, and extracted three times with $50 \mathrm{ml}$ of ethylacetate, further extracted with $20 \mathrm{ml}$ of sodium carbonate, reacidified, and finally extracted three times with ether ( $50 \mathrm{ml}$ each time). The pooled ether extracts were left overnight to evaporate under lab temperature and redissolved in $2 \mathrm{ml}$ ether, of which $0.05 \mathrm{ml}$ was spotted on precoated silica gel (Merck, Gf 254) and alumina (Eastman 6063) TLC plates. A mixture of liquid paraffin, benzene, acetic acid, and cyclohexane $(1: 3: 2: 20, \mathrm{v} / \mathrm{v} / \mathrm{v} / \mathrm{v})$ was used as a developing solvent. The radioactive spots on the TLC plates were located by autoradiography. ${ }^{7)}$ The radioactive spots were removed from the chromatograms by scraping and these samples were then radioassayed by liquid scintillation spectrometry. Quantitative assessments were also made by scanning the TLC plates for radioactive compounds using Packard radiochromatogram scanner model 7201.

The results are expressed as percentage of applied activity. The percentage values were converted to arcsines and subjected to analysis of variance as described by Snedecor and Cochran. ${ }^{8)} \quad$ Significant differences between means were determined by Duncan's multiple range analysis. ${ }^{9)}$

Experiments were also conducted to see whether MCPA affects differentially ${ }^{14} \mathrm{CO}_{2}$ fixation and ${ }^{14} \mathrm{C}$-assimilate translocation in the test species. Uniform plants of each species (two plants per pot) were sprayed just to run off with various concentrations of herbicide. The surfactant Tween-20 at $0.1 \%(\mathrm{v} / \mathrm{v})$ was added to the herbicide. The treated plants were then transferred to a growth chamber. The growth chamber conditions were similar to the ones described previously. On the 7th day, the second oldest leaf of each species was allowed to assimilate ${ }^{14} \mathrm{CO}_{2}$ using a modification of the method of Ismail. ${ }^{10)}$ The leaf was enclosed in a transparent perspex chamber $(6 \times 13.5 \times 8 \mathrm{~cm})$. The leaf was placed in a notch cut into the lower half of the chamber, 
and after replacing the top, the notch was sealed using silicone grease. ${ }^{14} \mathrm{CO}_{2}(5 \mu \mathrm{Ci} /$ leaf $)$ was liberated into the chamber from $\mathrm{Na}_{2}{ }^{14} \mathrm{CO}_{3}$ solution (specific activity, $59.5 \mathrm{mCi} / \mathrm{mmol}$ ) by the addition of $1 \mathrm{~N} \mathrm{HCl}$. The leaf was allowed to fix ${ }^{14} \mathrm{CO}_{2}$ for $15 \mathrm{~min}$ after which the remaining ${ }^{14} \mathrm{CO}_{2}$ was extracted by injecting $14 \%$ ethanolamine solution in methoxyethanol into a petri dish previously placed in the feeding assembly; the chamber was then removed. The plants were harvested after $48 \mathrm{hr}$ and divided into the treated leaf, shoot and root, freeze-dried, and weighed. Each region was then homogenized in $20 \mathrm{ml}$ of $90 \% \quad(\mathrm{v} / \mathrm{v})$ ethanol as described previously. A $0.5 \mathrm{ml}$ aliquot was placed in a scintillation vial and allowed to evaporate under lab temperature and radioassayed. The results are expressed in two ways as described by Ismail. ${ }^{10)}$ (1) Total ${ }^{14} \mathrm{C}$ recoveries were considered equal to $\mathrm{dpm} /$ fed leaf $+\mathrm{dpm} /$ shoot $+\mathrm{dpm}$ root; losses due to respiration were ignored and (2) the ${ }^{14} \mathrm{C}$ recovered in the whole plant, except the fed leaf, is expressed as percentage of the total recovery and regarded as total translocation.

\section{RESULTS AND DISCUSSION}

The phytotoxicity of a range of concentrations of MCPA on the test species under controlled conditions was assessed by visual symptoms (Table 1). Broad bean was susceptible, chickweed moderately susceptible and maize tolerant. Phytotoxic symptoms were virtually absent in maize at concentrations less than $5000 \mathrm{ppm}$. At high concentrations, chlorosis of older leaves and distortion of the roots was noted. Eddowes and Harpur ${ }^{11)}$ reported excellent control of weeds with postemergence application of MCPA $(1.25 \mathrm{~kg} / \mathrm{ha})$. But in maize, leaf rolling and distortion of prop roots was evident 3 weeks after spraying. In the present investigation, treatment of broad bean with high concentrations (>1000 ppm) produced epinasty, necrosis, severe wilting, lodging, and blackening of the foliage. In the case of chickweed, low concentrations caused epinasty of the younger leaves and at higher concentrations the older leaves showed necrosis.

There is evidence that after uptake, differences in translocation may be a factor in the selective action of certain herbicides. ${ }^{12,13)} \mathrm{Ex}$ -
Table 1 The toxicity of MCPA to maize, chickweed, and broad bean.

\begin{tabular}{cccc}
\hline \multirow{2}{*}{ Herbicide $(\mathrm{ppm})$} & \multicolumn{3}{c}{ Visual assessment $(0$ to 5$)$} \\
\cline { 2 - 4 } & Maize & Chickweed & Broad bean \\
\hline 0 & 0 & 0 & 0 \\
50 & 0 & 0 & 0 \\
100 & 0 & 0 & 0 \\
250 & 0 & 0 & 0 \\
500 & 0 & 2 & 4 \\
1000 & 0 & 2 & 4 \\
5000 & 1 & 2 & 4 \\
10000 & 1 & 3 & 5 \\
\hline
\end{tabular}

0 : no effect, 1: chlorosis of older leaves and distortion of roots, 2: epinasty of young leaves, 3: chlorosis of older leaves, 4: epinastic bending and wilting, 5: severe wilting and blackening of leaves.

amination of the distribution of ${ }^{14} \mathrm{C}-\mathrm{MCPA}$ within the test species revealed differentials in translocation (Fig. 1 and Table 2). The amount of ${ }^{14} \mathrm{C}$ translocated in broad bean and chickweed was about three and two times, respectively, greater than in maize. Most of ${ }^{14} \mathrm{C}$ translocated by broad bean accumulated in the root and shoot apices. The ratios of translocation to absorption were 0.39 , 0.21 , and 0.08 in broad bean, chickweed, and maize, respectively. Absorption was greater in maize than in the other two species. By using leaf-discs, Sargent and Blackman ${ }^{14)}$ compared the rates of uptake of 2,4-dichlorophenoxyacetic acid (2,4-D) in six species and found more rapid penetration into $Z e a$ (most resistant) than into Pisum, Beta, Helianthus, Gossypium or Phaseolus (all are sensitive to some extent). The relatively high absorption in maize did not result in increased translocation. The surface residue fraction accounts for most of the total recovered ${ }^{14} \mathrm{C}$ in chickweed whereas in maize, most of absorbed ${ }^{14} \mathrm{C}$ was retained by the treated leaf. Sanad ${ }^{3)}$ found a clear relationship between the susceptibility of corn cockle to the mobility of MCPA in this plant. Similarly, Collins and Gaunt ${ }^{1)}$ have reported on the uptake of MCPA by rape, red campion, and pea. They reported that in rape (susceptible), $50 \%$ of the label that entered the treated leaves was translocated to the rest 


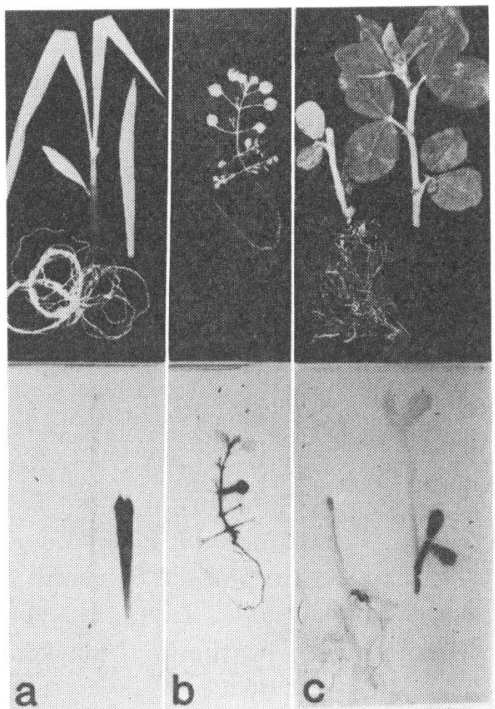

Fig. 1 Autoradiograms of maize (a), chickweed (b), and broad bean (c).

Samples above, autoradiograms below.

Table 2 The uptake and translocation of ${ }^{14} \mathrm{C}$ MCPA in maize, chickweed, and broad bean.

\begin{tabular}{lrrr}
\hline \multirow{2}{*}{ Regions } & \multicolumn{3}{c}{$\begin{array}{c}{ }^{14} \text { C-Distribution } \\
\% \text { of applied) }\end{array}$} \\
\cline { 2 - 4 } & Maize & Chickweed & Broad bean \\
\hline Surface residue & $12.5 \mathrm{a}$ & $31.2 \mathrm{~b}$ & $15.4 \mathrm{c}$ \\
Wax residue & $0.3 \mathrm{a}$ & $1.0 \mathrm{a}$ & $0.3 \mathrm{a}$ \\
Treated leaf & $30.1 \mathrm{a}$ & $21.1 \mathrm{~b}$ & $11.8 \mathrm{c}$ \\
Shoot & $1.7 \mathrm{a}$ & $4.2 \mathrm{~b}$ & $3.1 \mathrm{c}$ \\
Root & $0.8 \mathrm{a}$ & $1.7 \mathrm{~b}$ & $4.5 \mathrm{c}$ \\
\hline Recovery & $45.4 \mathrm{a}$ & $59.2 \mathrm{~b}$ & $35.1 \mathrm{c}$ \\
Absorption & $32.9 \mathrm{a}$ & $28.0 \mathrm{~b}$ & $19.7 \mathrm{~b}$ \\
\hline $\begin{array}{l}\text { Analysis of variance }(P): \\
\text { gions }=0.001 \text {; Species }=0.001 \text {; Re- }\end{array}$ \\
a) Duncan's multiple range test: values within \\
the same row (horizontal) with common \\
letter postscripts are not significantly differ- \\
ent at 5\% level.
\end{tabular}

of the plant; in pea and red campion (both tolerant) translocation was less extensive. The ${ }^{14} \mathrm{C}$ retained by the cuticle wax was limited and represented less than $1 \%$ (of the applied) and species did not differ significantly in this respect. It is worth noting that most of ${ }^{14} \mathrm{C}$ recovered in chickweed was detected as surface residue.
Table 3 The relative quantities of ${ }^{14} \mathrm{C}-\mathrm{MCPA}$ or its metabolites in various fractions of the test species

\begin{tabular}{|c|c|c|c|}
\hline \multirow{2}{*}{ Fraction } & \multicolumn{3}{|c|}{$\begin{array}{l}{ }^{14} \text { C-Distribution } \\
(\% \text { of applied })^{a)}\end{array}$} \\
\hline & Maize & Chickweed & Broad bean \\
\hline $\begin{array}{l}\text { Ethylacetate } \\
\text { fraction }\end{array}$ & $50.8 \mathrm{a}$ & $77.0 \mathrm{~b}$ & $43.6 \mathrm{c}$ \\
\hline Bound fraction & $3.2 \mathrm{a}$ & $0.3 \mathrm{~b}$ & $0.8 \mathrm{~b}$ \\
\hline${ }^{14} \mathrm{CO}_{2}$ evolved & $5.5 \mathrm{a}$ & $3.6 \mathrm{a}$ & $15.2 \mathrm{~b}$ \\
\hline $\begin{array}{l}{ }^{14} \mathrm{C}-\mathrm{MCPA} \\
\text { leached }\end{array}$ & $1.7 \mathrm{a}$ & $0.8 \mathrm{a}$ & $6.9 \mathrm{~b}$ \\
\hline \multicolumn{4}{|c|}{$\begin{array}{l}\text { a) Duncan's multiple range test: values within } \\
\text { the same row (horizontal) with common } \\
\text { letter postscripts are not significantly differ- } \\
\text { ent at } 5 \% \text { level. }\end{array}$} \\
\hline
\end{tabular}

The release of ${ }^{14} \mathrm{CO}_{2}$ from MCPA was greater in broad bean than in the other two species (Table 3) indicating faster rates of breakdown of MCPA in broad bean. In the case of broad bean, the loss of ${ }^{14} \mathrm{C}-\mathrm{MCPA}$ through the roots was $6.9 \%$ (of the applied dose) and may reflect the rapid accumulation of herbicide in the roots with a consequent increase in cell membrane permeability. A similar exudation into the soil following the foliar application of 2,4-D to Jimsonweed has been reported. ${ }^{15}$ Chromatography of ether extracts of the test species revealed some breakdown of the herbicide, but the results are inconclusive. The radioactive spots ( $R f$ value 0.0 ) with 78,9 , and $68 \%$ in maize, chickweed, and broad bean, respectively, were regarded as metabolites and were not further resolved. The other spot with $R f$ value 0.10 consisted of 24,76 , and $32 \%$ of the total radioactivity in maize, chickweed, and broad bean, respectively, and was identified as ${ }^{14} \mathrm{C}-\mathrm{MCPA}$.

The foliar application of MCPA resulted in inhibition of ${ }^{14} \mathrm{CO}_{2}$ fixation and ${ }^{14} \mathrm{C}$-assimilate translocation, the effect being particularly greater in sensitive species (Table 4). At relatively low concentrations (non-toxic levels) $(500 \mathrm{ppm}) \mathrm{MCPA}$ increased the export of photosynthates to the root in the test species, while at higher concentrations, there was a decrease in the level of export and shoot particularly in the sensitive species, broad bean and chickweed. The reduction in trans- 
Table 4 The effect of MCPA on ${ }^{14} \mathrm{CO}_{2}$ fixation and ${ }^{14} \mathrm{C}$-assimilate distribution in maize (M), chickweed (C), and broad bean (B).

\begin{tabular}{|c|c|c|c|c|c|}
\hline \multirow{2}{*}{$\begin{array}{l}\text { Concentration } \\
(\mathrm{ppm})\end{array}$} & \multirow{2}{*}{ Species } & \multicolumn{3}{|c|}{$\begin{array}{c}{ }^{14} \mathrm{C}-\text {-Distribution } \\
\left.(\% \text { of total recovery })^{a}\right)\end{array}$} & \multirow{2}{*}{$\begin{array}{c}\text { Total }{ }^{14} \mathrm{CO}_{2} \\
\text { fixation } \\
\left.\left(\mathrm{dpm} \times 10^{3}\right)^{\mathrm{a}}\right)\end{array}$} \\
\hline & & Fed leaf & Shoot & Root & \\
\hline \multirow[t]{3}{*}{0} & M & $36.3 \mathrm{a}$ & $39.5 \mathrm{~h}$ & $24.2 \mathrm{f}$ & $269.5 \mathrm{j}$ \\
\hline & $\mathrm{C}$ & $51.8 \mathrm{~cd}$ & $38.8 \mathrm{~h}$ & $9.4 \mathrm{c}$ & $41.6 \mathrm{~b}$ \\
\hline & $\mathrm{B}$ & $49.8 \mathrm{c}$ & $19.8 \mathrm{~d}$ & $30.4 \mathrm{~h}$ & $192.9 \mathrm{~g}$ \\
\hline \multirow[t]{3}{*}{500} & M & $42.4 \mathrm{~b}$ & $30.8 \mathrm{fg}$ & $26.8 \mathrm{~g}$ & $248.0 \mathrm{k}$ \\
\hline & $\mathrm{C}$ & $62.0 \mathrm{e}$ & $23.8 \mathrm{e}$ & $14.2 \mathrm{~d}$ & $35.2 \mathrm{ab}$ \\
\hline & $\mathrm{B}$ & $54.9 \mathrm{~d}$ & $11.6 \mathrm{~b}$ & $33.5 \mathrm{i}$ & $150.0 \mathrm{f}$ \\
\hline \multirow[t]{3}{*}{1000} & M & $49.9 \mathrm{c}$ & $28.6 \mathrm{f}$ & $21.5 \mathrm{e}$ & $228.4 \mathrm{i}$ \\
\hline & $\mathrm{C}$ & $64.8 \mathrm{f}$ & $22.6 \mathrm{e}$ & $12.8 \mathrm{~cd}$ & $32.5 \mathrm{ab}$ \\
\hline & B & $60.0 \mathrm{e}$ & $9.9 \mathrm{~b}$ & $30.1 \mathrm{~h}$ & $135.9 \mathrm{e}$ \\
\hline \multirow[t]{3}{*}{5000} & $\mathrm{M}$ & $54.7 \mathrm{~d}$ & $30.4 \mathrm{~g}$ & $14.9 \mathrm{c}$ & $220.5 \mathrm{i}$ \\
\hline & $\mathrm{C}$ & $70.1 \mathrm{~g}$ & $19.9 \mathrm{~d}$ & $10.0 \mathrm{c}$ & $30.5 \mathrm{a}$ \\
\hline & B & $69.9 \mathrm{~g}$ & $9.0 \mathrm{~b}$ & $21.1 \mathrm{e}$ & $120.5 \mathrm{~d}$ \\
\hline \multirow[t]{3}{*}{10000} & M & $60.1 \mathrm{e}$ & $19.3 \mathrm{~d}$ & $20.6 \mathrm{e}$ & $202.0 \mathrm{~h}$ \\
\hline & $\mathrm{C}$ & $75.0 \mathrm{~h}$ & $14.7 \mathrm{c}$ & $10.3 \mathrm{c}$ & $28.9 \mathrm{a}$ \\
\hline & B & $81.5 \mathrm{i}$ & $7.9 \mathrm{~b}$ & $10.6 \mathrm{e}$ & $100.5 \mathrm{c}$ \\
\hline
\end{tabular}

Analysis of variance $(P)$ : species, concentrations, regions (all $=0.001)$, spp/concs, spp/regs, conc/ regs, spp/conc/regs $($ all $=0.001)$.

a) Duncan's multiple range test: values within the same column (vertical) with common letter postscripts are not significantly different at the $5 \%$ level.

location of assimilates may be due to the creation of new sinks in the treated leaves ${ }^{16)}$ and/or to an inhibition of the loading process. It is noteworthy that the levels of ${ }^{14} \mathrm{CO}_{2}$ fixed and the rates of export of ${ }^{14} \mathrm{C}$-assimilates in maize controls were greater than broad bean and chickweed. These findings are in close agreement with the suggestion that $\mathrm{C}_{4}$ plants, such as maize, have reduced photorespiration, special leaf anatomy, biochemical pathways, and greater translocation capacities than $\mathrm{C}_{3}$ plants such as broad bean and chickweed. ${ }^{17-19)}$

\section{CONCLUSIONS}

The absorption of foliar applied ${ }^{14} \mathrm{C}-\mathrm{MCPA}$ was significantly greater in tolerant maize than sensitive broad bean or chickweed. However, the amount of ${ }^{14} \mathrm{C}-\mathrm{MCPA}$ translocated in broad bean or chickweed was greater than in maize. The foliar application of MCPA resulted in greater inhibition of ${ }^{14} \mathrm{CO}_{2}$ fixation and ${ }^{14} \mathrm{C}$-assimilate translocation in broad bean and chickweed than in maize.

\section{REFERENCES}

1) D. J. Collins \& J. K. Gaunt: Biochem. J. 124, $9(1971)$

2) R. C. Kirkwood, J. Dalziel, A. Matlib \& L. Sommerville: Pestic. Sci. 3, 307 (1972)

3) A. J. Sanad: Weed Res. 11, 215 (1971)

4) G. A. Bray: Anal. Biochem. 1, 279 (1960)

5) P. Veerasekaran: Mode of action of Asulam (methyl-4-aminobenzene sulphonyl carbamate) in Bracken [Pteridium aquilinum (L.) Kuhn.] $\mathrm{Ph}$.D. thesis, Univetsity of Strathclyde, Glasgow, Scotland (1975)

6) C. M. Facett, R. M. Pascal, M. B. Pybus, H. F. Taylor, R. T. Wain \& F. Wightman: Proc. $R$. Soc. 150, 95 (1959)

7) S. Yamaguchi \& A. S. Crafts: Hilgardia 28, 161 (1958)

8) G. W. Snedecor \& W. G. Cochran: "Statistical Methods," Iowa State University Press, Iowa, p. 299, 1967

9) D. B. Duncan: Biometrics 11, 1 (1955)

10) A. M. A. Ismail: Translocation in Vicia faba L. Ph. D. thesis, University of Wales, Bangor, Great Britain (1976)

11) M. Eddowes \& R. L. Harpur: Weed Res. 5, 
33 (1965)

12) S. W. Bingham \& R. Shaver: Weed Res. 19 , 639 (1971)

13) R. H. Strang \& R. L. Rogers: J. Agric. Food Chem. 22, 1119 (1974)

14) J. A. Sargent \& G. E. Blackman: J. Exp. Bot. 23, 830 (1972)

15) R. W. Neidermyer \& J. D. Nalewaja: Weed Sci. 17, 528 (1969)

16) O. A. Leonard, R. J. Weaver \& R. K. Glenn: Weed Res. 7, 108 (1967)

17) R. H. Brown; Crop Sci. 18, 93 (1978)

18) G. Hofstra \& C. D. Nelson: Planta 88, 103 (1969)

19) W. M. Lush: Planta 130, 235 (1976)
要約

\section{植物体内における MCPA の吸収，代謝および} 薬害

Nagi R. Achhireddy, Ralph C. Kirkwood, William W. Fletcher 制御された環境条件下で, MPCA に抵抗性を示すト ウモロコシ，やや感受性のハコベ，感受性のソラマメに 対し，MCPA の植物毒性を体内移行，代謝と関係づけ て検討した。ソラマメ，ハコベおよびトウモロコシにお ける ${ }^{14} \mathrm{C}-\mathrm{MCPA}$ の移行量は, それぞれ処理総量の 7.6, 5.9 および $2.5 \%$ であった. しかし処理葉における ${ }^{14} \mathrm{C}-$ MCPA の残量はソラマメ, ハコベに比べてトウモロコ シで多かった。葉部残量のうちクチクラワックス内には 処理量の $1 \%$ 以下にすぎず，この数值は 3 植物間に有意 な差は認められなかった. ${ }^{14} \mathrm{C}-\mathrm{MCPA}$ 処理による ${ }^{14} \mathrm{CO}_{2}$ の発生はトウモロコシ，ハコベに比べてソラマメにおい て明らかに多かった. MCPA の葉面処理により, ${ }^{14} \mathrm{CO}_{2}$ の固定およびその同化生成物の体内移行阻害はトウモ口 コシに比べてソラマメ，八コべで明らかに大きかった。 